\title{
Updates in the Treatment of Peripheral T-Cell Lymphomas
}

\author{
Khalil Saleh' \\ Jean-Marie Michot ${ }^{1,2}$ \\ Vincent Ribrag ${ }^{1,2}$ \\ 'Department of Hematology, Gustave \\ Roussy Cancer Campus, Villejuif, 94800, \\ France; ${ }^{2}$ Département d'Innovation \\ Thérapeutique et d'Essais Précoces \\ (DITEP), Gustave Roussy Cancer \\ Campus, Villejuif, 94800, France
}

\begin{abstract}
Peripheral T-cell lymphomas (PTCLs) represent a heterogeneous group of rare hematologic malignancies accounting for less than $10 \%$ of non-Hodgkin lymphomas. The 2016 classification of World Health Organization recognized 29 different entities of PTCLs. These subgroups are characterized by different molecular and genetic patterns. For nearly 30 years, little improvement in the treatment of PTCLs has been noticed due to the paucity of randomized trials and anthracycline-based chemotherapy remains the mainstay of first-line treatment. In front-line setting, ECHELON-2, the first randomized controlled Phase III clinical trial, recently met its primary endpoint of PFS demonstrating the superiority of BV containing regimen when compared to standard CHOP in patients with CD30 positive PTCLs. The role of therapeutic intensifications such as autologous or allogenic stem cell transplantations remains controversial in first-line setting and in relapsed/refractory disease due to the lack of studies clearly addressing this question and the recently published negative studies. PTCLs are often refractory to first-line chemotherapy and tend to relapse after an initial response. New agents have been approved for relapsed/refractory disease such as Histone deacetylase inhibitors, folate analogue metabolic inhibitor or CD30 antibody drug conjugated. Despite an acceptable response to these agents, progression-free survival remains very poor. New strategies such as combinations of different agents have been evaluated in order to improve outcomes. Innovative drugs in the fields of epigenetics, immunomodulation within the tumor microenvironment, and direct targeting of tumor cells to CD30 and T-cell receptor abnormalities open new perspectives to improve the treatment of PTCLs.
\end{abstract}

Keywords: peripheral T-cell lymphomas, brentuximab vedotin, HDAC inhibitors, immune checkpoint inhibitors, CHOP, stem cell transplantation

\section{Introduction}

Peripheral T-cell Lymphomas (PTCLs) represent a relatively rare disease accounting for 6-10\% of all cases of non-Hodgkin lymphomas (NHLs) in western countries. ${ }^{1}$ The incidence of PTCLs exhibits a geographical dependence, reaching $20-25 \%$ of NHLs in some parts in Asia and South America. ${ }^{2}$ PTCLs constitute a heterogeneous group of hematologic malignancies that differ in clinical behavior and anatomical location. The World Health Organization (WHO) recognizes at least 29 distinct entities of mature post thymic T-cell NHLs in the updated classification of hematological and lymphoid neoplasms. ${ }^{3}$ The last classification proposed several provisional subtypes and introduced the T-follicular helper (TFH) phenotype. TFH lymphoma and nodal T-cell lymphoma with TFH phenotype are thus separate subtypes different from PTCLs not otherwise specified (PTCL-NOS). PTCLs could be anatomically classified as nodal, extranodal, cutaneous and leukemic
Correspondence: Vincent Ribrag Department of Hematology, Gustave Roussy Cancer Campus, II 4 rue Edouard Vaillant, Villejuif, 94800, France

Tel +33 I 42 II 5954

Fax +33 I 42 II 5270

Email vincent.ribrag@gustaveroussy.fr 
forms (Table 1). The most frequent subtypes are PTCL-not otherwise specified (NOS) (30\% of PTCLs), angioimmunoblastic T-cell lymphoma (AILT; 15-30\% of PTCLs), anaplastic large T-cell lymphoma (ALCL; 15\% of PTCLs), extranodal natural killer (NK) cell/T cell lymphoma (ENKTCL; 10\% of PTCLs), and intestinal T cell lymphomas $(\sim 5-6 \%$ of PTCLs, including enteropathy-

Table I Mature T-Cell and NK-Cell Neoplasm Based on the WHO 2016 Classification

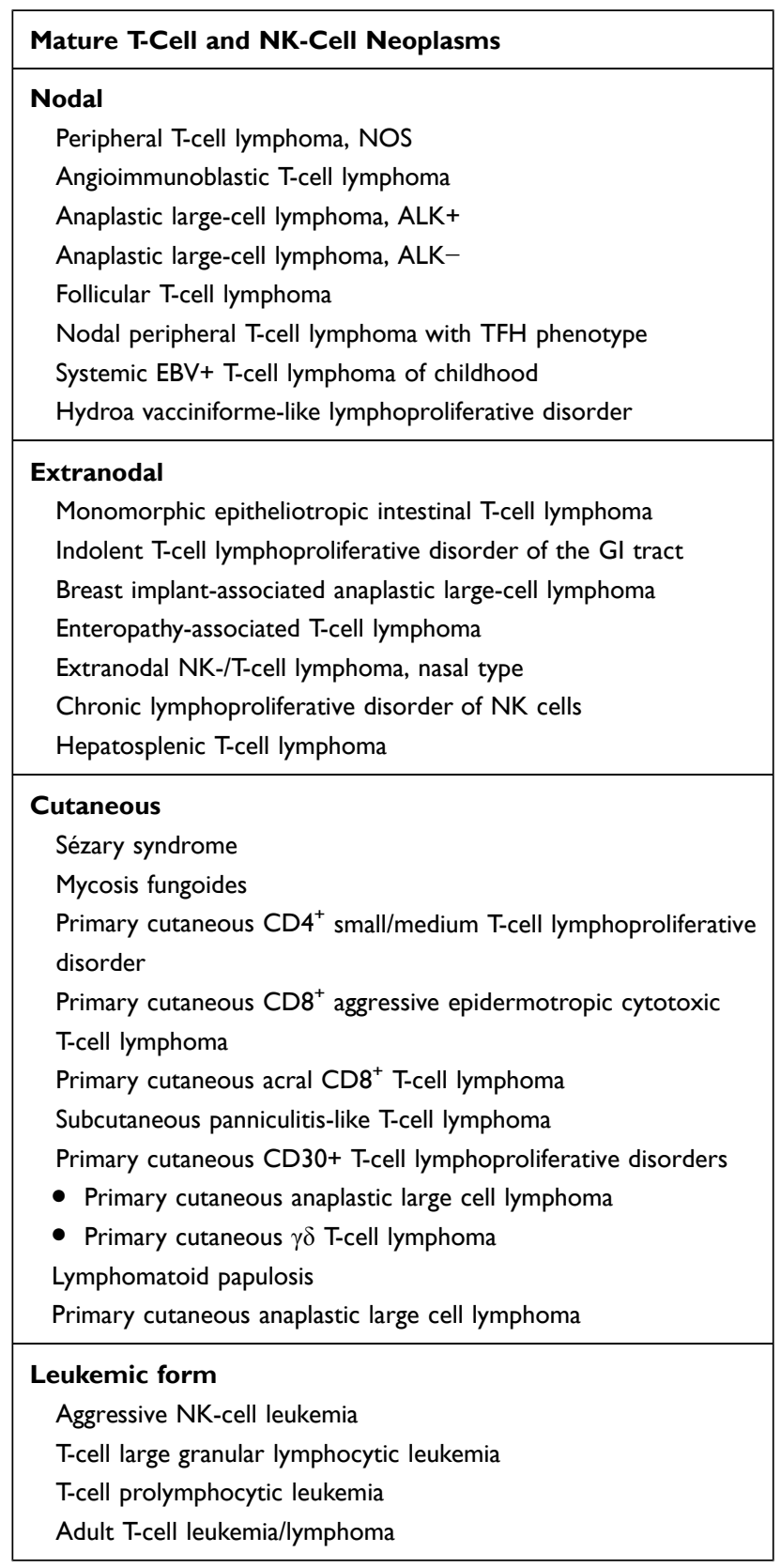

Note: Data based on the WHO 2016 classification data from Swerdlow et al. ${ }^{3}$ Abbreviations: GI, gastro-intestinal; NK, natural killer; NOS, not otherwise specified; ALK, anaplastic lymphoma kinase; TFH, T follicular helper; EBV, Epstein Barr virus. associated $\mathrm{T}$ cell lymphoma (EATL) and monomorphic epitheliotropic intestinal $\mathrm{T}$ cell lymphoma (MEITL). ${ }^{4}$ Adult T-cell leukemia/lymphoma (ATLL) is most commonly diagnosed in countries with a high prevalence of human T-cell lymphotropic virus type 1 (HTLV-1) infection, especially in Japan and the Caribbean. ${ }^{5}$ The intrinsic variability of PTCLs and their scarcity had stymied progress in the treatment outcome. Despite the recent major advances in the understanding of PTCLs, including new laboratory methods for diagnosis and new therapeutic approaches, the prognosis of the majority of PTCLs remains poorer than with aggressive B-cell lymphoma, except for anaplastic lymphoma kinase (ALK)-positive ALCL. The 5-year overall survival (OS) for ALK+ ALCL, ALK- ALCL, AITL, and PTCL-NOS is $80.2 \%$, $44.7 \%, 35.4 \%$, and $25.4 \%$, respectively. ${ }^{6}$ This review aims to discuss the molecular and genetic patterns of PTCLs, first-line treatment including bone marrow transplantation, as well as treatment of relapsed/refractory PTCLs and future therapeutic directions.

\section{Molecular and Genetic Patterns of PTCLs}

As previously mentioned, there are 29 different subtypes of PTCLs according to the 2016 WHO classification. PTCL-NOS harbors no specific characteristic immunophenotype. However, two subgroups have been identified using the Gene Expression Profiles (GEPs) with different gene expression driven by the transcription factors TBX21 or GATA-3. The GATA-3 PTCL-NOS subgroup has significantly poor survival outcomes. ${ }^{7,8}$

Patients with ALK+ ALCL most frequently present $\mathrm{t}(2 ; 5)$ that fuses nucleophosmin gene (NPM) with the ALK gene leading to an oncogenic tyrosine kinase (NPM-ALK) that promotes signaling of the JAK/STAT pathway. GEPs showed hyperactivation of STAT3 in ALCL caused mainly by ALK rearrangements or activating mutations in the JAK/STAT pathway. Based on rearrangements revealed by cytogenetics, ALK negative patients could be classified into three groups: DUSP22 +, TP63 +, and triple negative group (ALK-, DUSP22- and TP63-). ALK-negative ALCLs have chromosomal rearrangements of DUSP22 or TP63 in 30\% and 8\% of the cases respectively. DUSP22-rearranged cases have favorable outcomes similarly to ALK+ ALCLs, whereas other genetic variants have inferior outcomes. ${ }^{9}$

The molecular profiling of other PTCLs revealed several mutations of genes involved in DNA methylation such as 
TET2, IDH2 and DNMT3. ${ }^{10}$ TET2 mutations have been described in $47 \%$ of patients with AITL, and in $38 \%$ of patients with PTCL-NOS. This high incidence in PTCL-NOS is probably related to the TFH phenotype being included in this subgroup in the previous 2008 WHO classification. ${ }^{11}$ Furthermore, $76 \%$ of patients with AITL have TET2 mutations. ${ }^{10}$ DNMT3A mutations occurred in $33 \%$ of patients with AITL, and are frequently associated with TET2 mutations ( $100 \%$ of the patients with reference to Odejide et al). IDH2 mutations, initially reported in patients with acute myeloid leukemia (AML) and Glioblastoma Multiforme, had also been found in 20 to $45 \%$ of patients with AITL, and were detected in different loci. ${ }^{12}$ Moreover, IDH2 mutations cooccur frequently with TET 2 mutations. ${ }^{10}$ These mutations are highly reported in patients with AITL (67\%), and less frequently in patients with PTCL-NOS (18\%). RHOA mutations do not seem to have an epigenetic influence, despite being associated with T-cell proliferation and invasiveness. ${ }^{13,14}$ GEPs revealed multiple mutations in patients with ATLL such as RHOA, TET2, loss-of-function mutations in TP53, and overexpression of PD-L1. ${ }^{15}$

Other interesting mutations in PTCLs are those affecting T-cell receptor (TCR)-related genes such as PLCG1 (14\%), CD28 (9\%, exclusively in AITL), PI3K elements (7\%), CTNNB1 (6\%), and GTF2I (6\%). More importantly, most variants in TCR-related genes represent gain-of-function mutations that could be addressed by new potential drugs. ${ }^{16}$

Activating mutations in TCR pathway genes had also been reported especially in patients with AITL and PTCLNOS leading to lymphomagenesis by activating NF-kB pathway. The most common mutation leads to PLCG1 and was also described in CTCL. ${ }^{17}$

\section{First-Line Treatment of PTCLs}

Due to the paucity of randomized clinical trials in this setting, no clear gold standard exists for the treatment of patients with newly diagnosed PTCLs. Treatment regimens are extrapolated from those initially developed in aggressive B-cell lymphoma. CHOP (cyclophosphamide, Adriamycin, vincristine and prednisolone) or CHOP-like regimens have been widely considered as the standard of care in patients with newly diagnosed PTCLs. Controlled studies are rare and the largest studies in PTCLs are retrospective. Up to one-third of patients with PTCLs may progress during first-line treatment. ${ }^{18}$ The adoption of CHOP regimen was initially based on the results of a large randomized phase III clinical trial of patients with highgrade and/or advanced stage B-cell or T-cell NHLs. This study compared CHOP with more dose-dense regimens (MACOP-
B, ProMACE-CytaBOM and m-BACOD), and failed to demonstrate a significant benefit when compared to CHOP. ${ }^{19}$ Reyes et al found that ACVBP was superior to CHOP in patients with low-risk localized aggressive lymphoma. ${ }^{20}$ More intense chemotherapy regimens such as hyperCVAD (hyperfractionated cyclophosphamide, vincristine, doxorubicin, and dexamethasone followed by methotrexate and cytarabine) and DA-EPOCH (dose-adjusted etoposide, prednisone, vincristine, cyclophosphamide, doxorubicin, and rituximab) showed good results in terms of response rate and progressionfree survival (PFS), but at the cost of higher myelosuppression rates leading to poor treatment adherence and early deaths. ${ }^{21,22}$ Retrospective and non-randomized studies suggested that the addition of etoposide to CHOP (CHOEP) in young and fit patients could be associated with a better outcome. ${ }^{23,24}$

More recently, the results of the first multicenter, double blind, randomized, placebo-controlled phase III trial in PTCLs were reported. The ECHELON-2 compared brentuximab vedotin (BV), cyclophosphamide, doxorubicin and prednisone $(\mathrm{BV}+\mathrm{CHP})$ with the standard $\mathrm{CHOP}$ regimen in previously untreated CD30+ PTCLs. The study met its primary endpoint of PFS, demonstrating the superiority of BV containing regimen. At a median follow-up of 36 months, $\mathrm{BV}+\mathrm{CHP}$ was associated with significantly longer PFS than CHOP: 48.2 months (95\% CI, 35.2-not reached) vs 20.4 months $(95 \% \mathrm{CI}, 12.7-47.6)$, with a hazard ratio $0.71(95 \%$ CI, 0.54-0.93, $\mathrm{p}=0.0110)$. The 3-year PFS rate was $57.1 \%$ (95\% CI, 49.9-63.7\%) for the BV + CHP arm versus $44.4 \%$ (95\% CI, 37.6-50.9\%) for the CHOP arm. The two groups had similar adverse events, including incidence and severity of febrile neutropenia (41 [18\%] patients in the BV + CHP group and 33 [15\%] in the CHOP group) and peripheral neuropathy $(117$ [52\%] in the $\mathrm{BV}+\mathrm{CHP}$ group and 124 $[55 \%]$ in the CHOP group). ${ }^{25}$ In addition, more than $70 \%$ of patients included in the trial had ALCL including ALK+ or ALK- disease, an entity characterized by high expression of CD30. Importantly, the inclusion criteria of the ECHELON-2 trial required an expression of at least $10 \%$ of CD30 on tumor cells. Based on the results of this trial, The Food and Drug Administration (FDA) approved the $\mathrm{BV}+\mathrm{CHP}$ regimen in patients with CD30+ PTCLs in November 2018. ${ }^{26}$ Nowadays, most experts recognize BV + CHP treatment as standard of care for patients with any level CD30+ ALCL. However, the debate concerning the extrapolation of the results to other histologic subtypes continues since the ECHELON-2 trial was not powered enough to answer this question by performing histology-based subgroup analysis. In fact, the European Medicines Agency (EMA) restricted 
the approval of $\mathrm{BV}+\mathrm{CHP}$ to the patients with $\mathrm{CD} 30+$ systemic ALCL only.

Histone deacetylase inhibitor (HDACi) romidepsin can be combined with CHOP in the first-line setting. ${ }^{27}$ It has been investigated in a phase III randomized double-blind trial in comparison with standard CHOP. The addition of romidepsin to CHOP did not improve PFS, the primary endpoint of the study. In addition, response rates and OS were similar with the combination. ${ }^{28}$ Other combinations are ongoing in for previously untreated PCTLs patients, and are summarized in Table 2.

\section{Autologous Stem Cell}

\section{Transplantation in Upfront Setting}

The role of autologous stem cell transplantation (ASCT) in patients with PTCLs is controversial due to limited data, heterogeneous populations in the current studies, and the lack of randomized trials clearly evaluating ASCT procedure. ASCT has been investigated to prevent the high relapse rate in chemosensitive patients. ${ }^{29}$ The largest prospective studies based on cohort or registry were conducted by the Nordic Lymphoma Group, the German Group, Lysa French group, and United States of America group. The Nordic Lymphoma Group trial enrolled 160 patients with a confirmed diagnosis of PTCLs excluding those with ALK+ ALCL. Patients received 6 cycles of biweekly CHOEP-14 except for those aged 60 years and older who received CHOP-14. One hundred fifteen patients underwent ASCT. At a median follow-up of 60.5 months, OS rate was $51 \%$ and PFS rate was $44 \%$. Patients with $\mathrm{ALK}^{-}$ALCL had the highest OS and PFS ( $70 \%$ and $61 \%$, respectively) compared with other histological subtypes (PTCL-NOS, AITL and EATL). The differences between the four groups were not statistically significant. ${ }^{30}$ In the German study, the second largest prospective trial reported by Reimer et al, 83 patients with newly diagnosed PTCLs were enrolled. Patients received 4 to 6 cycles of CHOP followed by mobilization, and those who were in CR or PR underwent myeloablative chemo-radiotherapy (fractionated total-body irradiation

Table 2 Novel Combinations Under Investigation in Previously Untreated PTCLs

\begin{tabular}{|c|c|c|c|c|c|}
\hline Agent(s) & $\begin{array}{l}\text { ClinicalTrials. } \\
\text { gov }\end{array}$ & Phase & $\mathbf{N}$ & Treatment & $\begin{array}{l}\text { Primary } \\
\text { Endpoint(s) }\end{array}$ \\
\hline $\begin{array}{l}\text { Decitabine }+ \\
\text { CHOP vs } \\
\text { CHOP }\end{array}$ & NCT03553537 & III & 100 & $\begin{array}{l}\text { Experimental arm: decitabine } 10 \mathrm{mg} / \mathrm{m}^{2} \text { on day I to } 5+\mathrm{CHOP} \\
\text { on day } 6 \text { every } 4 \text { weeks for } 6 \text { cycles } \\
\text { Control arm: CHOP Q3 weeks for } 6 \text { cycles }\end{array}$ & PFS \\
\hline $\begin{array}{l}\text { CDOP vs } \\
\text { CHOP }\end{array}$ & NCT03952572 & III & 244 & $\begin{array}{l}\text { Experimental arm: pegylated liposomal doxorubicin }+ \\
\text { cyclophosphamide + vincristine }+ \text { prednisone Q3 weeks for } 6 \text { cycles } \\
\text { Control arm: CHOP Q3 weeks for } 6 \text { cycles }\end{array}$ & $C R$ and $P R$ rates \\
\hline $\begin{array}{l}\text { Romidepsin + } \\
\text { CHOEP + } \\
\text { HSCT }\end{array}$ & NCT02223208 & $\mathrm{I} / \mathrm{II}$ & 110 & $\begin{array}{l}\text { Phase I: romidepsin dose escalation on days I and } 8+\text { CHOEP } 2 \text { I } \\
\text { Phase II: Romidepsin on days I and } 8+\text { CHOEP } 2 \text { I } \\
\text { In phase I and II } 3 \text { cycles and if CR or PR } 3 \text { additional cycles followed } \\
\text { by HSCT } \\
\text { CR followed by ASCT } \\
\text { PR followed by allogenic SCT }\end{array}$ & $\begin{array}{l}\text { DLT } \\
\text { PFS }\end{array}$ \\
\hline $\begin{array}{l}\text { CC-486 (oral } \\
5-\text { Azacitidine) }+ \\
\text { CHOP }\end{array}$ & NCT03542266 & II & 20 & $\begin{array}{l}\text { CC- } 486300 \mathrm{mg} \text { PO daily day }-6 \text { to } 0 \text { of cycle I and day } 8 \text { to } 2 \text { I } \\
\text { during cycles I to } 5 \\
\text { CHOP Q3 weeks for } 6 \text { cycles }\end{array}$ & $\mathrm{CR}$ rate \\
\hline $\begin{array}{l}\text { Romidepsin + } \\
\text { lenalidomide }\end{array}$ & NCT022325I6 & II & 35 & $\begin{array}{l}\text { Romidepsin on days I, } 8 \text { and I } 5 \text { and lenalidomide daily on days I to } \\
2 \text { I on a } 28 \text {-day cycle for up to I year in the absence of PD or } \\
\text { unacceptable toxicity }\end{array}$ & $\begin{array}{l}\text { Efficacy of the } \\
\text { combination }\end{array}$ \\
\hline $\begin{array}{l}\text { Nivolumab + } \\
\text { standard DA- } \\
\text { EPOCH }\end{array}$ & NCT03586999 & II & 18 & Nivolumab IV + DA-EPOCH Q3 weeks for 6 cycles & $\begin{array}{l}\text { Incidence of TEAE } \\
\text { Efficacy (ORR, CR } \\
\text { rate, } P R \text { rate, } S D \\
\text { rate, } P D \text { rate) }\end{array}$ \\
\hline
\end{tabular}

Abbreviations: PFS, progression-free survival; CR, complete response; PR, partial response; DLT, dose-limiting toxicity; TEAE, treatment-emergent adverse events; ORR, objective response rate; SD, stable disease; PD, progressive disease; HSCT, hematological stem cell transplantation; ASCT, autologous stem cell transplantation; SCT, stem cell transplantation; PO, per os; IV, intravenously. 
and high-dose cyclophosphamide) and ASCT. Fifty-five $(66 \%)$ of the 83 patients received transplantation. The main reason for not receiving ASCT was progressive disease. At a median follow-up of 33 months, the estimated 3-year OS was $48 \%$ for the intention-to treat population. Failure to achieve CR was associated with markedly inferior results. ${ }^{31}$ More recently, the role of up-front ASCT in PTCLs for responders after induction was reported by the French LYSA study. Two hundred sixty-nine patients were analyzed; they had mostly PTCLNOS, AITL, or ALK + ALCL with partial $(\mathrm{N}=52,19 \%)$ or complete response $(\mathrm{N}=217,81 \%)$ after induction. One hundred and thirty-four patients were allocated to ASCT in ITT, and 135 were not. The median PFS was 3.7 years, and the median OS was 8.4 years for the entire cohort. No OS difference was observed according to histological subtype. The authors failed to depict a survival advantage in favor of ASCT as a consolidation procedure for patients who responded after induction. Subgroup analyses did not reveal any further difference for patients with respect to response status, stage disease, or risk category. ${ }^{29}$ Moreover, a large multi-center prospective study was reported from the COMPLETE registry (Comprehensive Oncology Measures for Peripheral T-cell Lymphoma Treatment). This cohort compared the survival outcomes in patients with nodal PTCLs who received or not consolidative ASCT in the upfront setting. The authors did not find any statistical difference in terms of survival between the ASCT and non-ASCT groups. They also suggested that subgroups of patients with nodal PTCLs, especially those with AITL and/or high-risk features (advanced-stage disease or intermediate-to-high IPI scores), might benefit from consolidative ASCT in terms of initial complete response. ${ }^{32}$

Collectively, these results did not sufficiently support the use of ASCT for up-front consolidation in patients with PTCLs in complete or partial response after induction therapy. The role of consolidative ASCT after first remission needs to be defined in prospective randomized trials.

\section{Autologous Stem Cell Transplantation in Relapsed PTCL Setting}

Evidence for ASCT in the relapsed/refractory $(\mathrm{R} / \mathrm{R})$ setting is scarce and comes from registry data and retrospective studies. The results suggest that the outcomes could be improved with the use of consolidation HSCT, with the most benefiting group being the ALCL subtype, reaching a 3 -years OS of $50 \%$ and a PFS of $65 \%{ }^{33}$ Data from the CIBMTR registry revealed no significant difference in survival between ASCT and allogenic stem cell transplantation (SCT), although a 34\% TRM was reported with allogenic SCT by contrast to only $6 \%$ with $\mathrm{ASCT}^{34}$ All these results show that SCT could be considered for eligible patients in the salvage setting and in chemotherapysensitive patients who have never had it before.

\section{Allogenic Stem Cell Transplantation}

The role of allogenic SCT has been investigated recently by a randomized Phase 3 trial comparing ASCT and allogenic SCT as part of first-line therapy in poor-risk PTCL patients. ${ }^{35}$ Patients received conventional chemotherapy with 4 cycles of CHOEP and 1 cycle of DHAP followed by intensification. Patients were randomized to receive BEAM followed by ASCT or myeloablative conditioning (fludarabine, busulfan, cyclophosphamide) followed by allogenic SCT from a matched related or unrelated donor. One hundred and three patients were enrolled (ASCT: 54, allogenic SCT: 49), of whom 36 35\%) could not proceed to transplantation mostly due to early disease progression. The 3-year event-free survival (EFS) and OS did not significantly differ between allogenic SCT and ASCT (EFS: $43 \%$ vs $38 \%, p=0.58$, and $57 \%$ vs $70 \%$, $\mathrm{p}=0.41$ respectively). However, the treatment-related mortality (TRM) after allogenic SCT was $31 \%$, with no reported deaths after ASCT. In younger patients with T-cell lymphoma, standard chemotherapy consolidated by either autologous or allogeneic transplantation result in comparable survival, thus eliminating a role for allogenic stem cell transplantation in the first-line setting. ${ }^{35}$ These results are in line with the retrospective analysis of the MD Anderson Cancer Center for patients with PTCLs that failed to show any difference in outcomes between ASCT and allogenic SCT. In addition, a CR prior to SCT initiation was associated with improved outcomes. ${ }^{36}$

In a prospective Phase II trial, Corradini et al evaluated the graft-versus-lymphoma effect of reduced-intensity conditioning (RIC) (thiotepa, cyclophosphamide and fludarabine) followed by allogenic SCT in relapsed PTCLs. Seventeen patients were enrolled, of whom two had chemo-refractory disease and 15 had relapsed disease. Eight patients (47\%) had disease relapse after ASCT. Salvage therapy consisted of 4 to 6 cycles of DHAP followed by RIC and allogenic SCT. At a median followup of 28 months, the estimated 3-year OS and PFS rates were $81 \%$ and $64 \%$ respectively, and the transplantationrelated mortality rate was $12 \%$. Donor lymphocyte infusions induced a response in two patients progressing after 
Table 3 Approved Agents for the Treatment of PTCLs

\begin{tabular}{|c|c|c|c|c|c|c|c|c|}
\hline Agent & Target & Phase & $\mathbf{N}$ & $\begin{array}{l}\text { ORR (\%) } \\
\text { CR (\%) }\end{array}$ & $\begin{array}{l}\text { Median } \\
\text { DOR } \\
\text { (Months) }\end{array}$ & $\begin{array}{l}\text { Median } \\
\text { PFS } \\
\text { (Months) }\end{array}$ & $\begin{array}{l}\text { Median } \\
\text { OS } \\
\text { (Months) }\end{array}$ & AEs Grade $\geq 3$ \\
\hline Pralatrexate ${ }^{39}$ & Antifolate & II (PROPEL) & 111 & $\begin{array}{l}29 \\
11\end{array}$ & 10.1 & 3.5 & 14.5 & $\begin{array}{l}\text { Thrombocytopenia }(32 \%) \text {, } \\
\text { mucositis }(22 \%) \text {, neutropenia } \\
(22 \%) \text {, anemia }(18 \%)\end{array}$ \\
\hline Romidepsin ${ }^{43}$ & $\begin{array}{l}\text { HDAC-I } \\
\text { inhibitor }\end{array}$ & II & 130 & $\begin{array}{l}25 \\
15\end{array}$ & 17 & 4 & 11.3 & $\begin{array}{l}\text { Thrombocytopenia }(24 \%) \text {, } \\
\text { neutropenia }(20 \%) \text {, infections } \\
(19 \%)\end{array}$ \\
\hline Belinostat $^{44}$ & $\begin{array}{l}\text { Pan-HDAC } \\
\text { inhibitor }\end{array}$ & II (BELIEF) & 129 & $\begin{array}{l}25.8 \\
10.8\end{array}$ & 13.6 & 1.6 & 7.9 & $\begin{array}{l}\text { Anemia }(10.8 \%) \text {, } \\
\text { thrombocytopenia }(7 \%), \\
\text { neutropenia }(6.2 \%) \text {, dyspnea } \\
(6.2 \%)\end{array}$ \\
\hline $\begin{array}{l}\text { Brentuximab } \\
\text { vedotin }{ }^{46} \mathrm{ALCL}\end{array}$ & $\begin{array}{l}\text { CD30 } \\
\text { antibody }\end{array}$ & II & 58 & $\begin{array}{l}86 \\
57\end{array}$ & 12.6 & 13.3 & $\begin{array}{l}\text { Not } \\
\text { reached }\end{array}$ & $\begin{array}{l}\text { Neutropenia }(21 \%), \\
\text { thrombocytopenia (14\%), } \\
\text { peripheral sensory neuropathy } \\
(12 \%)\end{array}$ \\
\hline Chidamide $^{45}$ & $\begin{array}{l}\text { HDACI/ } \\
2 \text { inhibitor }\end{array}$ & II (Chinese) & 79 & $\begin{array}{l}28 \\
14\end{array}$ & 9.9 & 2.1 & 21.4 & $\begin{array}{l}\text { Thrombocytopenia }(22 \%) \text {, } \\
\text { leucopenia (I3\%), neutropenia } \\
\text { (1 } 1 \%)\end{array}$ \\
\hline Mogamulizumab $^{47}$ & $\begin{array}{l}\text { Anti-CCR4 } \\
\text { Antibody }\end{array}$ & II (Japanese) & 37 & $\begin{array}{l}35 \\
14\end{array}$ & $\begin{array}{l}\text { Not } \\
\text { reported }\end{array}$ & 3.0 & $\begin{array}{l}\text { Not } \\
\text { reached }\end{array}$ & $\begin{array}{l}\text { Lymphocytopenia }(73 \%), \\
\text { neutropenia }(19 \%), \\
\text { leukocytopenia }(14 \%)\end{array}$ \\
\hline
\end{tabular}

Abbreviations: ORR, objective response rate; CR, complete response; DOR, duration of response; PFS, progression-free survival; OS, overall survival; $A E$, adverse events; HDAC, histone deacetylase; CCR4, chemokine receptor 4.

transplantation, suggesting the existence of a graft-versuslymphoma effect. ${ }^{37}$

Zain et al retrospectively reported the results of a case series of patients with R/R PTCLs, undergoing related or unrelated donors' allogenic SCT between 2000 and 2007. Thirty-seven pretreated patients were enrolled, 68\% (25 patients) of whom had either relapsed or progressive disease. All patients were ineligible for ASCT. Thirteen patients received fully ablative conditioning regimens, while 24 patients underwent reduced-intensity conditioning. The 5-year OS and PFS were 52.2\% and 46.5\%, respectively. At the time of analysis, nine $(24.3 \%)$ patients had either relapsed $(n=6)$ or progressed $(n=3)$ post allogenic SCT. At 5 years, the cumulative incidences of non-relapse and relapse/progression mortality were $28.9 \%$ and $24.3 \%$, respectively. There were no statistically significant predictors for survival or relapse by univariate Cox regression analysis of disease and patient characteristics; differences between CTCL and other histologies were not significant. The relapse/progression curves reached and maintained a plateau after 1 year post- transplant, demonstrating that long-term disease control is possible after allogenic SCT in patients with PTCLs with advanced disease. ${ }^{38}$ Collectively, these results indicate that allogenic SCT remains an option in patients with R/R PTCLs.

\section{Treatment of Relapsed/Refractory PTCLs}

\section{Approved Treatment for PTCLs}

In relapsing patients, the subsequent treatment is not clearly defined. Conventional chemotherapy and/or autologous or allogenic SCT may result in disease control in a small number of patients. New drug development is the most promising way to improve survival for patients with $\mathrm{R} / \mathrm{R}$ disease. Over the past decade, the FDA approved 4 new agents for the treatment of R/ R PTCLs: pralatrexate, romidepsin, belinostat, and brentuximab vedotin. Two other drugs are approved in China and Japan. These molecules showed a single-agent activity based on the results of published phase II trials summarized in Table 3. However, the EMA did not recognize pralatrexate, romidepsin, and belinostat for the treatment of patients with PTCLs. In 
fact, these agents were associated with a good response rate, yet the PFS remains largely unchanged in this high risk group of patients.

\section{Folate Analogue Metabolic Inhibitor}

Pralatrexate, a novel folate analogue metabolic inhibitor with high affinity for reduced folate carrier type 1 (RFC1), was the first drug approved for the treatment of relapsed and/or refractory PTCLs in September 2009 based on the results of the PROPEL study (Pralatrexate in Patients with Relapsed or Refractory Peripheral T-Cell Lymphoma). Pralatrexate was given intravenously weekly at a dosage of $30 \mathrm{mg} / \mathrm{m}^{2}$ for 6 weeks in a 7-week cycle. The ORR was $29 \% .{ }^{39}$ Maruyama et al reported the results of a Japanese phase I/II trial evaluating pralatrexate in 20 patients with R/R PTCLs. The ORR was $45 \%$, including two CR; median PFS was 150 days. The median duration of response (DOR) and OS were not reached, and the safety profile was comparable to the PROPEL study. ${ }^{40}$ More recently, Hong et al published the outcomes of a single-arm multicenter study of 71 patients with $R / R$ PTCLs after a median of two previous treatment lines. The ORR was $52 \%$ with a median DOR of 8.7 months, median PFS of 4.8 months, and median OS of 18.0 months. ${ }^{41}$ This suggests that earlier treatment with pralatrexate may be associated with better clinical outcome.

\section{HDAC Inhibitors}

Romidepsin is a bicyclic class 1 selective HDAC inhibitor. It has been isolated form Chromobacterium violaceum. In June 2011, the FDA approved romidepsin for the treatment of patients with R/R PTCLs who have progressed after at least one systemic therapy regimen. In a phase II trial conducted by the National Cancer Institute, the ORR with romidepsin in patients with R/R PTCLs was 38\%, and the median DOR was 8.9 months. ${ }^{42}$ The pivotal registration-directed phase II trial enrolled 130 patients who were treated with romidepsin $14 \mathrm{mg} / \mathrm{m}^{2}$ intravenously on days 1,8 and 15 every 28-day cycle. Coiffier et al reported an ORR of $25 \%$ including $15 \% \mathrm{CR} / \mathrm{CRu}$ (unconfirmed CR) with a median PFS of 4 months and median DOR of 28 months among responders, leading to an accelerated FDA approval. $^{43}$

Belinostat, a hydroxamic acid-derived pan-class I and II HDAC inhibitor, has also been approved by the FDA in July 2014 for the treatment of patients with R/R PTCLs who failed at least one previous treatment line. This was based on the results of the pivotal phase II BELIEF trial, a multicenter open label trial of belinostat in patients with relapsed or refractory T-cell lymphoma. A total of 129 patients were enrolled and received $1000 \mathrm{mg} / \mathrm{m}^{2}$ of belinostat on days 1-5 in 21-day cycles. The median number of previous treatment lines was 2 , and the authors reported an ORR of $25.8 \%$ including $10.8 \%$ CRs. Patients with PTCLNOS achieved an ORR of 23\%, those with AITL had an ORR of $46 \%$, and patients with ALK- ALCL had an ORR of $15 \%$. The median DOR, PFS and OS were 13.6 months, 1.6 months, and 7.9 months, respectively. ${ }^{44}$

Chidamide is an oral class I/II HDAC inhibitor that has been studied in a pivotal Chinese phase II trial in patients with R/R PTCLs (mainly PTCL-NOS, ALCL, ENKTL, and AITL). Eighty-three patients had been enrolled and received chidamide $30 \mathrm{mg}$ orally twice per week. The ORR was $28 \%$ including $14 \%$ of $\mathrm{CR} / \mathrm{CRu}$. The median PFS was 2.1 months and the median OS was 21.4 months. ${ }^{45}$ Based on these results, chidamide was approved only in China for the treatment of patients with $R / R$ PTCLs.

\section{CD30 Antibody Drug Conjugated}

Brentuximab vedotin is the fourth drug approved by the FDA for the treatment of patients with $R / R$ ALCL in August 2011, and extended for primary CTCL and CD30expressing Mycosis Fungoides in November 2017. In a pivotal phase II trial, BV was evaluated for patients with $\mathrm{R} / \mathrm{R}$ systemic ALCL. It was administered intravenously as single-agent at a dose of $1.8 \mathrm{mg} / \mathrm{kg}$ every 3 weeks for up to 16 cycles. Fifty-eight patients were enrolled; the ORR was $86 \%$ with $57 \%$ of CR, and the median PFS was 13.6 months. Among patients who achieved CR, 5-year OS was 79\% and 5-year PFS was $57 \%{ }^{46}$ These data led to approval of BV in the USA, European Union, and Japan for patients with sALCL. Many ongoing trials are evaluating the combination of BV with other drugs in both relapsed and upfront settings.

\section{Chemokine Receptor 4 (CCR4) Monoclonal Antibody}

Mogamulizumab is a defucosylated humanized $\operatorname{IgG1}$ monoclonal antibody that targets $\mathrm{CC}$ chemokine receptor 4 (CCR4) which is mainly expressed in ALK- ALCL, PTCL-NOS, AITL, and transformed mycosis fungoides. It was approved in Japan for patients with $\mathrm{R} / \mathrm{R} \mathrm{CCR} 4+$ ATLL and cutaneous T-cell lymphoma based on the results of a multicenter phase II trial evaluating mogamulizumab for the treatment of patients with relapsed ATLL. The 
study enrolled 28 patients who received intravenous infusions of mogamulizumab once per week for 8 weeks at a dose of $1.0 \mathrm{mg} / \mathrm{kg}$. The ORR was $50 \%$ including $30 \%$ of CR. Median PFS and OS were 5.2 months and 13.7 months, respectively. ${ }^{47}$ Furthermore, mogamulizumab was approved in the USA for the treatment of R/R mycosis fungoides and Sezary syndrome.

\section{Agents Investigated in R/R PTCLs ALK Inhibitors}

Crizotinib, an oral ALK-ROS1-MET inhibitor, was associated with an ORR of $90 \%$ in a pediatric study of 26 patients having $R / R$ ALK + ALCL with a good safety profile. Among the 23 patients who achieved a response, $39 \%$ maintained their response for at least 6 months, and $22 \%$ maintained their response for at least 12 months. ${ }^{48}$ Crizotinib was approved by the FDA for the treatment of patients with $\mathrm{R} / \mathrm{R}$ ALK + ALCL in children and young adults in January 2021.

\section{$\mathrm{PI3}$ Kinase and mTOR/AKT Inhibitors}

Duvelisib, an oral PI3K-delta-gamma inhibitor was associated with an ORR of 50\% in PTCL, and $31.6 \%$ in CTCL with 3 complete responses in a phase II trial when used as monotherapy for patients with R/R PTCLs. ${ }^{49}$ Everolimus, an oral mammalian target of rapamycin (mTOR) pathway inhibitor, given at $10 \mathrm{mg}$ daily continuously resulted in an ORR of $44 \%$ in a phase II trial of 16 patients with $R / R$ PTCL. The median PFS was 4.1 months and the median OS was 10.2 months. Six patients (38\%) required a dose reduction to $5 \mathrm{mg}$ daily. ${ }^{50}$

\section{Hypomethylating Agents}

Hypomethylating agents (HMAs), initially approved for the treatment of AML and myelodysplastic syndrome, have been studied in R/R PTCLs. HMAs are the pharmacologic counterbalance of epigenetics modified tumor by IDH2, TET2 and DNMT3A mutations. ${ }^{12}$ 5-Azacitidine used as monotherapy at a dose of $75 \mathrm{mg} /$ $\mathrm{m}^{2}$ subcutaneously for 7 consecutive days every 28days cycle in patients with AITL was associated with an ORR of $75 \%(9 / 12)$ and CR rate of $50 \%(6 / 12)$. Patients presented durable responses with a median PFS and OS of 15 and 21 months, respectively. ${ }^{51} \mathrm{An}$ ongoing phase III trial is comparing oral 5-Azacitidine with investigator's choice therapy (romidepsin, bendamustine or gemcitabine) in patients with $\mathrm{R} / \mathrm{R}$ AITL (NCT03593018).

\section{Immunomodulatory Agent}

Lenalidomide, an immunomodulatory agent targeting cereblon and aiolos/ikaros transcription factors and approved in B-cell NHL and multiple myeloma, has shown modest activity when used as monotherapy in the EXPECT phase II trial with an ORR of $22 \% .{ }^{52}$ In patients with R/R ATLL, lenalidomide demonstrated clinically meaningful antitumor activity with an ORR of $42 \%$ including $4 \mathrm{CR}$ and 1 unconfirmed $\mathrm{CR}$ in a multicenter phase II trial. ${ }^{53}$

\section{Immune Checkpoint Inhibitors}

Programmed death-ligand 1 (PD-L1) was mainly detected in AITL $(>90 \%)$ and PTCL-NOS (30-60\%), and rarely in other subtypes. ${ }^{54}$ In NKTCL, PD-L1 expression ranged between 56 and $93 \%$ in different studies, while PD-1 level was consistently low. ${ }^{55}$ In addition, Kataoka et al demonstrated that PDL1 amplifications represent a strong genetic predictor of worse outcomes in patients with both aggressive and indolent ATLL. ${ }^{56}$ The efficacy of nivolumab, a PD-1 inhibitor, was evaluated in a Phase I, open-label, dose-escalation, cohort expansion trial for the treatment of patients with $\mathrm{R} / \mathrm{R}$ TCL. Twenty-three patients were enrolled. The ORR among these patients was $17 \%{ }^{57}$ In a retrospective case series, pembrolizumab, another PD-1 inhibitor, showed high efficacy (100\%) in 7 patients with $\mathrm{R} / \mathrm{R} \mathrm{NK} / \mathrm{T}$ cell lymphoma that relapsed after treatment with L-asparaginase. Complete response was observed in 5 patients $(71 \%)$, and this was sustained after a median follow-up of 6 months. ${ }^{58}$ In a multicenter singlearm phase II trial, pembrolizumab given at a dosage of $200 \mathrm{mg}$ intravenously every three weeks, was evaluated for patients with R/R PTCLs. Of 18 enrolled patients, 13 were evaluable for the primary endpoint. The ORR was $33 \%$, with 4 patients showing a CR. The median PFS was 3.2 months and the median OS was 10.6 months. The median duration of response was 2.9 months. Two of the 4 patients who presented CR remained in remission for at least 15 months. The trial was halted early after a preplanned interim futility analysis. ${ }^{59} \mathrm{PD}-1$ inhibitors had modest activity when used as monotherapy and these drugs could be more active when combined with another agent such as HDAC inhibitors, HMAs, or antifolates. Table 4 summarizes the major clinical trials evaluating novel combinations of immunotherapy in R/R PTCLs.

\section{Selected Interesting Combinations in R/R PTCLs}

A new strategy was adopted for the treatment of patients with $R / R$ PTCLs based on the combination of approved 
Table 4 Novel Combinations of Immunotherapy Under Investigation in R/R PTCLs

\begin{tabular}{|c|c|c|c|c|c|}
\hline Agent(s) & $\begin{array}{l}\text { ClinicalTrials. } \\
\text { gov }\end{array}$ & Phase & $\mathbf{N}$ & Treatment & $\begin{array}{l}\text { Primary } \\
\text { Endpoint(s) }\end{array}$ \\
\hline Pembrolizumab + romidepsin & NCT03278782 & $\mathrm{I} / \mathrm{II}$ & 39 & $\begin{array}{l}\text { Romidepsin IV on days I and } 8 \text { and pembrolizumab IV } \\
\text { on day I. Cycles repeat every } 2 \text { I days for up to } 36 \\
\text { cycles in the absence of disease progression or } \\
\text { unacceptable toxicity. }\end{array}$ & $\begin{array}{l}\text { DLT (phase I) } \\
\text { ORR (phase II) }\end{array}$ \\
\hline Pembrolizumab + pralatrexate & NCT03598998 & $\mathrm{I} / \mathrm{II}$ & 40 & $\begin{array}{l}\text { Pralatrexate IV on days I and } 8 \text {, pembrolizumab IV } \\
\text { on day I. Courses repeat every } 2 \text { I days for up to } 24 \\
\text { months in the absence of disease progression or } \\
\text { unacceptable toxicity. }\end{array}$ & $\begin{array}{l}\text { MTD (phase I) } \\
\text { ORR (phase II) }\end{array}$ \\
\hline Durvalumab \pm lenalidomide & NCT030II8I4 & $1 / I I$ & 62 & $\begin{array}{l}\text { Arm I: durvalumab IV on day I repeated every } 28 \\
( \pm 3) \text { days for up to I } 3 \text { courses in the absence of } \\
\text { disease progression or unacceptable toxicity. } \\
\text { Arm II: durvalumab IV on day I and lenalidomide PO } \\
\text { QD on days I- } 2 \text { I. Treatment repeated every } 28( \pm 3) \\
\text { days for up to I3 courses in the absence of disease } \\
\text { progression or unacceptable toxicity. }\end{array}$ & $\begin{array}{l}\text { CTCL specific } \\
\text { response assessed } \\
\text { by Lugano } \\
\text { Classification } \\
\text { Dose limiting } \\
\text { toxicity assessed by } \\
\text { CTCAE version } \\
4.03 \\
\text { Duration of } \\
\text { complete response } \\
\text { EFS } \\
\text { Incidence of AEs } \\
\text { ORR } \\
\text { OS } \\
\text { PFS } \\
\text { DOR } \\
\text { Time to response }\end{array}$ \\
\hline $\begin{array}{l}\text { Durvalumab }+ \text { pralatrexate, } \\
\text { romidepsin and oral } \\
5 \text {-Azacitidine }\end{array}$ & NCT03 I6I 223 & $\mathrm{I} / \mathrm{II}$ & 148 & $\begin{array}{l}\text { Arm A: } 7 \text {-day lead-in phase of } 5 \text {-azacitidine. } \\
\text { 5-azacitidine PO from day I to day I4, durvalumab IV } \\
\text { on day } 8 \text { and romidepsin IV on days } 8 \text { and I5 of a } 28 \text { - } \\
\text { day treatment cycle } \\
\text { Arm B: Durvalumab IV on day I, pralatrexate IV on } \\
\text { days I and I5, and romidepsin IV on days I and I5 on } \\
\text { a } 28 \text {-day cycle } \\
\text { Arm C: Durvalumab IV on day I and romidepsin IV on } \\
\text { days I, } 8 \text {, and I5 of a } 28 \text {-day cycle } \\
\text { Arm D: } 7 \text {-day lead-in phase of } 5 \text {-azacitidine. } \\
5 \text {-azacitidine PO from day I to day I } 4 \text { and durvalumab } \\
\text { IV on day } 8 \text { of a } 28 \text {-day cycle }\end{array}$ & MTD \\
\hline $\begin{array}{l}\text { Pembrolizumab }+ \text { decitabine }+ \\
\text { pralatrexate }\end{array}$ & NCT032402II & $\mathrm{lb}$ & 42 & $\begin{array}{l}\text { Arm A: pembrolizumab } 200 \mathrm{mg} \text { IV day I with } \\
\text { pralatrexate } 30 \mathrm{mg} / \mathrm{m} 2 \mathrm{IV} \text { day I, } 8 \text {, and I5 } \\
\text { Arm B: pembrolizumab } 200 \mathrm{mg} \text { IV day } 8 \text { with } \\
\text { pralatrexate } 20 \mathrm{mg} / \mathrm{m} 2 \text { IV day I, } 8 \text {, and I5 and } \\
\text { decitabine } 10 \mathrm{mg} / \mathrm{m} 2 \text { from day I to } 5 \\
\text { Arm C: pembrolizumab } 200 \mathrm{mg} \text { IV and decitabine } \\
20 \mathrm{mg} / \mathrm{m} 2 \text { from day I to } 5\end{array}$ & $\begin{array}{l}\text { Estimated MTD } \\
\text { Recommended } \\
\text { phase II dose }\end{array}$ \\
\hline
\end{tabular}

Abbreviations: DLT, dose limiting toxicity; ORR, objective response rate; MTD, maximum tolerated dose; EFS, event-free survival; CR, complete response; DOR, duration of response; PFS, progression-free survival; OS, overall survival; AE, adverse events; IV, intravenously; PO, per os. 
Table 5 Experimental Combinations of Approved Agents in R/R PTCLs

\begin{tabular}{|c|c|c|c|c|c|c|c|}
\hline Agent & Trial & $\begin{array}{l}\mathbf{N} \text { of } \\
\text { PTCLs }\end{array}$ & $\begin{array}{l}\text { ORR (\%) } \\
\text { CR (\%) }\end{array}$ & $\begin{array}{l}\text { Median } \\
\text { DOR } \\
\text { (Months) }\end{array}$ & $\begin{array}{l}\text { PFS } \\
\text { (Months) } \\
95 \% \mathrm{Cl}\end{array}$ & $\begin{array}{l}\text { OS } \\
\text { (Months) } \\
95 \% \mathrm{Cl}\end{array}$ & Grade $\geq 3$ AEs \\
\hline Romidepsin + pralatrexate ${ }^{61}$ & $\mathrm{I} / \mathrm{II}$ & 14 & $\begin{array}{l}71 \\
40\end{array}$ & 4.29 & 4.4 (I.2-NR) & I 2.4 (8.I-NR) & $\begin{array}{l}\text { Anemia (29\%), Thrombocytopenia } \\
(28 \%) \text {, Febrile neutropenia (14\%), } \\
\text { Mucositis oral (14\%), Sepsis (7\%) }\end{array}$ \\
\hline $\begin{array}{l}\text { Romidepsin }+ \text { oral } \\
\text { Azacitidine }^{63}\end{array}$ & I & 11 & $\begin{array}{l}73 \\
55\end{array}$ & $\begin{array}{l}\text { Not } \\
\text { reached }\end{array}$ & $\begin{array}{l}\text { Not } \\
\text { reached }\end{array}$ & Not reported & $\begin{array}{l}\text { Neutropenia ( } 42 \%) \text {, lymphopenia } \\
(42 \%) \text {, thrombocytopenia }(27 \%) \text {, } \\
\text { hypotension }(12 \%) \text {, hyponatremia } \\
(8 \%)\end{array}$ \\
\hline Romidepsin + duvelisib ${ }^{64}$ & I/II & 35 & $\begin{array}{l}51 \\
17\end{array}$ & 9.1 & 8.8 (NA) & Not reported & $\begin{array}{l}\text { Neutropenia (I8\%), increased ALT/ } \\
\text { AST (I5\%), hyponatremia ( } 12 \%)\end{array}$ \\
\hline Duvelisib + bortezomib ${ }^{64}$ & $\mathrm{I} / \mathrm{II}$ & 28 & $\begin{array}{l}32 \\
11\end{array}$ & 9.3 & 3.5 (NA) & Not reported & $\begin{array}{l}\text { Neutropenia }(18 \%) \text {, I pt with } \\
\text { grade } 5 \text { Stevens-Johnson } \\
\text { syndrome }\end{array}$ \\
\hline $\begin{array}{l}\text { Romidepsin + lenalidomide }^{79} \\
(\text { NCT022325I6) }\end{array}$ & $\mathrm{I} / \mathrm{II}$ & 21 & $\begin{array}{l}53 \\
10.5\end{array}$ & $\begin{array}{l}\text { Not } \\
\text { reported }\end{array}$ & I5.3 weeks & Not reached & $\begin{array}{l}\text { Neutropenia }(48 \%) \text {, } \\
\text { thrombocytopenia }(38 \%) \text {, anemia } \\
(33 \%)\end{array}$ \\
\hline $\begin{array}{l}\text { Romidepsin + carfilzomib + } \\
\text { lenalidomide }^{79}\end{array}$ & $\mathrm{I} / \mathrm{II}$ & 17 & $\begin{array}{l}50 \\
31\end{array}$ & 9.6 weeks & 9.7 weeks & Not reported & $\begin{array}{l}\text { Neutropenia and } \\
\text { thrombocytopenia in more than } \\
10 \% \text { of pts }\end{array}$ \\
\hline Bortezomib + panobinostat ${ }^{65}$ & II & 25 & $\begin{array}{l}43 \\
22\end{array}$ & 5.6 & 2.6 & 9.9 & $\begin{array}{l}\text { Thrombocytopenia }(68 \%) \text {, } \\
\text { neutropenia ( } 40 \%) \text {, diarrhea ( } 20 \%) \text {, } \\
\text { asthenia }(8 \%)\end{array}$ \\
\hline
\end{tabular}

Abbreviations: ORR, objective response rate; CR, complete response; DOR, duration of response; PFS, progression-free survival; OS, overall survival; AE, adverse events.

and non-approved medications in the field. Available data concerning these combinations are summarized in Table 5. However, most of these data are reported from small single-center studies without central pathology review.

\section{Romidepsin Plus Pralatrexate}

Romidepsin is an HDAC inhibitor approved for $\mathrm{R} / \mathrm{R}$ PTCLs. In preclinical models of PTCLs, romidepsin and pralatrexate showed a potent synergy in in-vitro and invivo models at dose levels of $50 \%$ of the maximal tolerated dose (MTD). ${ }^{60}$ Amengual et al reported the results of the first Phase I trial evaluating the combination of these two drugs to determine the MTD, pharmacokinetic profile, and response rate. Pralatrexate $25 \mathrm{mg} / \mathrm{m} 2$ and romidepsin $12 \mathrm{mg} / \mathrm{m} 2$ administered concurrently every other week were recommended for the Phase 2 trial. In this phase I study, the ORR for all patients was $57 \%(13 / 23)$, whereas the response rate in patients with PTCLs was $71 \%(10 / 14)$, and 33\% (3/9) in patients with B-cell lymphoma. ${ }^{61}$ The phase II trial is still ongoing (NCT01947140).

\section{Romidepsin Plus 5-Azacitidine}

The combination of HDACi and HMAs could be a novel approach for the treatment of PTCLs, targeting the epigenetic dysregulation of the disease. Marchi et al demonstrated a marked synergy between HDACi and HMAs in preclinical models of PTCLs. ${ }^{62}$ The encouraging results of a multicenter phase I trial evaluating the combination of romidepsin and oral 5-Azacitidine in R/R PTCLs were recently reported. The ORR for all patients was $32 \%$, for non-TCL was $10 \%$, and $73 \%$ for patients with T-cell lymphoma. The $\mathrm{CR}$ rates were $23 \%, 5 \%$ and $55 \%$, respectively. The MTD retained for phase 2 trial was 5-Azacitidine $300 \mathrm{mg}$ on days 1 to 14 and romidepsin $14 \mathrm{mg} / \mathrm{m} 2$ on days 8,15 and 22 of a 35 -day cycle. ${ }^{63}$ The phase II trial is still ongoing (NCT01998035).

\section{Romidepsin and Duvelisib}

A novel interesting combination in the treatment of $\mathrm{R} / \mathrm{R}$ PTCLs is the association of HDACi and duvelisib. The results of the phase I/II trial evaluating the association of 
duvelisib and romidepsin were reported in an abstract form by Horwitz et al The MTD of duvelisib was 75mg BID on days 1 to 28 , given with romidepsin $10 \mathrm{mg} / \mathrm{m}^{2}$ on days 1,8 and 15 of a 28 -day cycle. The ORR was $55 \%$, and CR occurred in $27 \%$ of the patients. Grade 3 or higher adverse events were seen in $65 \%$ of patients. ${ }^{64}$ These results suggest that romidepsin + duvelisib could be a potential therapeutic strategy to be evaluated in larger studies.

\section{Panobinostat and Bortezomib}

Another experimental combination was the association of HDACi and proteasome inhibitors based on the activity and the efficacy of these two classes in PTCLs. Tan et al reported the results of a phase II trial evaluating the combination of panobinostat and bortezomib. Patients received $20 \mathrm{mg}$ oral panobinostat three times a week and $1.3 \mathrm{mg} / \mathrm{m}(2)$ intravenous bortezomib two times a week, both for 2 of 3 weeks for up to eight cycles. The ORR was 43\% (10 of 23 patients), and the CR rate was $22 \%$ ( 5 of 23 patients). However, the PFS was very limited, which can be attributed to the short response time in highly aggressive disease. ${ }^{65}$

\section{Future Directions with Selected Innovative Chemo-Free Drugs for PCTLs}

(a) New epigenetic drugs. As described above, PTCLs are characterized by the frequency of alterations in histone methylation and acetylation genes. New drugs that target the epigenome, proliferative signaling pathways, and the tumor microenvironment are in clinical development. EZH2, encoding for histone-lysine $\mathrm{N}$-methyltransferase enzyme, is a therapeutic target. DS-3201b, an EZH1/2 inhibitor, has shown in vitro activity against lymphoma cell lines. ${ }^{66}$ An ongoing international multicenter phase I trial is evaluating DS-3201b in patients with lymphomas including PTCLs (NCT02732275). Preliminary results published as abstract and presented at ASH 2017 showed an encouraging ORR of $80 \%$ in patients with $\mathrm{R} / \mathrm{R}$ TCLs. However, this study suffered from an extremely low patient number (1CR and 3 PR of 5 patients). ${ }^{67}$ AG-221, an IDH2 inhibitor approved in patients with AML, has been studied in patients with advanced solid tumors harboring IDH2 mutation including R/R AITL. The results of this phase I/II trial have not been published yet, more than 3 years after study completion (NCT02273739). (b) JAK inhibitors. A phase II trial is evaluating the efficacy of ruxolitinib, a JAK1/2 inhibitor in R/R lymphomas including PTCLs (NCT01431209). Preliminary results showed that ruxolitinib can produce response in patients with R/R PTCL. ${ }^{68}$ Cerdulatinib, an oral inhibitor of the spleen-associated tyrosine kinase (SYK), JAK1, and JAK3, has also shown interesting activity in PTCL. In a phase II study involving 45 patients with PTCL and 25 with cutaneous T cell lymphoma, the ORR was 35\%. ${ }^{69}$ These early studies demonstrate that targeting the JAK/STAT pathway can be clinically beneficial for those patients.

(c) Apoptotic inhibitors. Apoptosis or programmed cell death is often altered in cancer cells, and can be prevented by overexpression of anti-apoptotic proteins, such as BCL2, MCL1, XIAP, and cIAP. ${ }^{70}$ These antiapoptotic proteins are key regulators of pro-survival signaling pathways, and their deregulation through overexpression or loss of endogenous antagonists occurs in various cancer types such as T-cell lymphoma. ${ }^{70}$ Venetoclax, a BCL-2 inhibitor that has been approved for the treatment of chronic lymphocytic leukemia and AML, is now being investigated in FIL_VERT study. It is an open-label, multicenter phase II clinical trial enrolling patients with BCL-2-positive TCL including PTCL-NOS and AITL (NCT03552692). ASTX660 is an oral novel nonpeptidomimetic small-molecule antagonist of cellular/ $\mathrm{X}$-linked inhibitors of apoptosis proteins (cIAP1/2 and XIAP). It is currently being evaluated in a first-inhuman Phase 1-2 study in patients with lymphoma (NCT02503423).

(d) Anti-CD38 monoclonal antibodies. ENKTL is characterized by the high expression of CD38. ${ }^{71}$ Daratumumab, a monoclonal anti-CD38 antibody approved for the treatment of multiple myeloma, showed an ORR of $25 \%$ when used as monotherapy in patients with R/R ENKTL in a phase II trial. $^{72}$ A multicenter phase II trial will evaluate the association of daratumumab with gemcitabine, dexamethasone, and cisplatin in patients with $\mathrm{R} / \mathrm{R}$ CD38+ PTCL-NOS, AITL, and other nodal lymphomas of Tfh cell origin (NCT04251065).

(e) Bi-specific CD30 based immunotherapy. T cells and NK cells are immunologic effector cells with the potential to fight cancer via tumor cell lysis. Bispecific antibodies targeting CD30 positive tumor cells were investigated in phase 1 clinical studies in the context 
of Hodgkin lymphoma: an anti-CD30 $\times \mathrm{CD} 16$ and an anti-CD30 $\times$ CD64 antibody. ${ }^{73,74}$ AFM13 is a first-inclass tetravalent bispecific antibody that specifically binds to CD30 on tumor cells and to CD16a on NK cells. It is now entering a registration directed phase II (REDIRECT) trial in patients R/R CD30+ T-cell lymphoma or transformed mycosis fungoides (NCT04101331).

(f) Immune checkpoint inhibitors (other than antiPD1). Another approach to treat patients with PTCLs is targeting tumor microenvironment using ICI. Among the checkpoints other than PD-1, ICOS is widely expressed in some T-cell lymphoma, and its targeting promotes potent tumor cell killing. ${ }^{75}$ MEDI-570 is a monoclonal antibody that targets ICOS, a member of the CD28/CTLA-4 family. An ongoing phase I trial is evaluating MEDI-570 for the treatment of patients R/R PTCL follicular variant and AITL (NCT02520791).

(g) Cell therapy for T-cell lymphoma. Chimeric antigen receptor T (CAR-T) cell based therapy is another innovative technique which is being investigated in patients with R/R PTCLs. In an open-label phase I trial, CD30targeting CAR-T cell was associated with an ORR of $39 \%$ (7/18 patients with partial response) in patients with R/R Hodgkin Lymphoma (HL). ${ }^{76}$ Ramos et al reported the results of another phase I trial evaluating CD30-specific CAR-T cell in 9 patients with R/R HL (7 patients) or ALCL ( 2 patients). One patient with ALK+ ALCL presented CR lasting for 9 months; the other patient with cutaneous ALK- ALCL showed no response to CAR-T cell. ${ }^{77} \mathrm{~A}$ single-center, open-label phase I trial is now evaluating CD30-specific CAR-T cell therapy in patients with R/R PTCLs and HL (NCT04008394). Furthermore, a phase II trial is now studying another CD30-specific CAR-T cell in patients with R/R CD30+ PTCLs (NCT04083495). Several other CAR-T cells are being evaluated in clinical trials targeting CD7, CD5 or CD4. The most encouraging approach is targeting TCR in order to eradicate malignant $\mathrm{T}$ cell clones. The efficacy and specificity of CAR$\mathrm{T}$ cells that target TCR $\beta$-chain constant domain (TRBC1) in vivo and in vitro have been reported by Maciocia et al. ${ }^{78}$

\section{Conclusion}

The management of patients with PTCLs remains challenging, with slow progress being made in the field, and only few drugs are currently approved. This is mainly due to the rarity of the disease and its aggressiveness, much complicating trial recruitment. Furthermore, given the various biological and molecular patterns, and the increasingly precise dissection of the molecular and immunological abnormalities of the disease, international collaboration seems crucial, and pan T-cell lymphomas trials are more and more regarded as a failed strategy. Innovative drugs targeting epigenetic mechanisms, immune checkpoint modulations, CD30 and TCR abnormalities with cellular therapies portend much hope to improve the outcomes of these patients in the upcoming years.

\section{Disclosure}

Dr Jean-Marie Michot reports being a principal/subinvestigator of clinical trials for Abbvie, Amgen, Astex, AstraZeneca, Debiopharm, Lilly, Roche, and Xencor, during the conduct of the study. Dr Vincent Ribrag reports non-financial support from Astex, Abbvie, BMS, Sanofi, and Servier, grants and non-financial support from Argenx, personal fees from Gilead, Roche, Incyte, and Nanostring, and personal fees and non-financial support from MSD and AZ, during the conduct of the study. The authors report no other potential conflicts of interest for this work.

\section{References}

1. Vose J, Armitage J, Weisenburger D. International T-cell lymphoma project. International peripheral T-cell and natural killer/T-cell lymphoma study: pathology findings and clinical outcomes. J Clin Oncol. 2008;26(25):4124-4130. doi:10.1200/JCO.2008.16.4558

2. d'Amore F, Gaulard P, Trümper L, et al. Peripheral T-cell lymphomas: ESMO clinical practice guidelines for diagnosis, treatment and follow-up. Ann Oncol. 2015;26(Suppl 5):v108-115. doi:10.1093/ annonc/mdv201

3. Swerdlow SH, Campo E, Pileri SA, et al. The 2016 revision of the World Health Organization classification of lymphoid neoplasms. Blood. 2016;127(20):2375-2390. doi:10.1182/blood-2016-01-643569

4. Fiore D, Cappelli LV, Broccoli A, Zinzani PL, Chan WC, Inghirami G. Peripheral T cell lymphomas: from the bench to the clinic. Nat Rev Cancer. 2020;20(6):323-342. doi:10.1038/s41568-020-0247-0

5. Hermine O, Ramos JC, Tobinai KA. Review of new findings in adult T-cell leukemia-lymphoma: a focus on current and emerging treatment strategies. Adv Ther. 2018;35(2):135-152. doi:10.1007/s12325-0180658-4

6. Timmins MA, Wagner SD, Ahearne MJ. The new biology of PTCL-NOS and AITL: current status and future clinical impact. $\mathrm{Br}$ J Haematol. 2020;189(1):54-66. doi:10.1111/bjh.16428

7. Iqbal J, Wright $\mathrm{G}$, Wang $\mathrm{C}$, et al. Gene expression signatures delineate biological and prognostic subgroups in peripheral T-cell lymphoma. Blood. 2014;123(19):2915-2923. doi:10.1182/blood-2013-11-536359

8. Wang T, Feldman AL, Wada DA, et al. GATA-3 expression identifies a high-risk subset of PTCL, NOS with distinct molecular and clinical features. Blood. 2014;123(19):3007-3015. doi:10.1182/blood-2013-12-544809 
9. Parrilla Castellar ER, Jaffe ES, Said JW, et al. ALK-negative anaplastic large cell lymphoma is a genetically heterogeneous disease with widely disparate clinical outcomes. Blood. 2014;124 (9):1473-1480. doi:10.1182/blood-2014-04-571091

10. Odejide $\mathrm{O}$, Weigert $\mathrm{O}$, Lane AA, et al. A targeted mutational landscape of angioimmunoblastic T-cell lymphoma. Blood. 2014;123 (9):1293-1296. doi:10.1182/blood-2013-10-531509

11. Lemonnier F, Couronné L, Parrens M, et al. Recurrent TET2 mutations in peripheral T-cell lymphomas correlate with TFH-like features and adverse clinical parameters. Blood. 2012;120(7):1466-1469. doi:10.1182/blood-2012-02-408542

12. Marchi E, O'Connor OA. The rapidly changing landscape in mature T-cell lymphoma (MTCL) biology and management. CA Cancer J Clin. 2020;70(1):47-70. doi:10.3322/caac.21589

13. Palomero T, Couronné L, Khiabanian $\mathrm{H}$, et al. Recurrent mutations in epigenetic regulators, RHOA and FYN kinase in peripheral $\mathrm{T}$ cell lymphomas. Nat Genet. 2014;46(2):166-170. doi:10.1038/ng.2873

14. Sakata-Yanagimoto M, Enami T, Yoshida K, et al. Somatic RHOA mutation in angioimmunoblastic $\mathrm{T}$ cell lymphoma. Nat Genet. 2014;46(2):171-175. doi:10.1038/ng.2872

15. Kataoka K, Nagata Y, Kitanaka A, et al. Integrated molecular analysis of adult $\mathrm{T}$ cell leukemia/lymphoma. Nat Genet. 2015;47 (11):1304-1315. doi:10.1038/ng.3415

16. Vallois D, Dobay MPD, Morin RD, et al. Activating mutations in genes related to TCR signaling in angioimmunoblastic and other follicular helper T-cell-derived lymphomas. Blood. 2016;128 (11):1490-1502. doi:10.1182/blood-2016-02-698977

17. Rohr J, Guo S, Huo J, et al. Recurrent activating mutations of CD28 in peripheral T-cell lymphomas. Leukemia. 2016;30(5):1062-1070. doi:10.1038/leu.2015.357

18. Ghez D, Danu A, Ribrag V. Investigational drugs for T-cell lymphoma. Expert Opin Investig Drugs. 2016;25(2):171-181. doi:10.1517/13543784.2016.1121994

19. Fisher RI, Gaynor ER, Dahlberg S, et al. Comparison of a standard regimen (CHOP) with three intensive chemotherapy regimens for advanced non-Hodgkin's lymphoma. $N$ Engl J Med. 1993;328 (14):1002-1006. doi:10.1056/NEJM199304083281404

20. Reyes F, Lepage E, Ganem G, et al. ACVBP versus CHOP plus radiotherapy for localized aggressive lymphoma. $N$ Engl $J$ Med. 2005;352(12):1197-1205. doi:10.1056/NEJMoa042040

21. Escalón MP, Liu NS, Yang Y, et al. Prognostic factors and treatment of patients with T-cell non-Hodgkin lymphoma: the M. D. Anderson Cancer Center experience. Cancer. 2005;103(10):2091-2098. doi:10.1002/cncr.20999

22. Maeda Y, Nishimori H, Yoshida I, et al. Dose-adjusted EPOCH chemotherapy for untreated peripheral T-cell lymphomas: a multicenter phase II trial of west-JHOG PTCL0707. Haematologica. 2017;102(12):2097-2103. doi:10.3324/haematol.2017.167742

23. Schmitz N, Trümper L, Ziepert M, et al. Treatment and prognosis of mature T-cell and NK-cell lymphoma: an analysis of patients with T-cell lymphoma treated in studies of the German High-Grade Non-Hodgkin Lymphoma Study Group. Blood. 2010;116 (18):3418-3425. doi:10.1182/blood-2010-02-270785

24. Ellin F, Landström J, Jerkeman M, Relander T. Real-world data on prognostic factors and treatment in peripheral T-cell lymphomas: a study from the Swedish lymphoma registry. Blood. 2014;124 (10):1570-1577. doi:10.1182/blood-2014-04-573089

25. Horwitz S, O'Connor OA, Pro B, et al. Brentuximab vedotin with chemotherapy for CD30-positive peripheral T-cell lymphoma (ECHELON-2): a global, double-blind, randomised, phase 3 trial. Lancet. 2019;393 (10168):229-240. doi:10.1016/S0140-6736(18)32984-2

26. Research $\mathrm{C}$ for DE and FDA approves brentuximab vedotin for previously untreated sALCL and CD30-expressing PTCL. FDA; December 20, 2019. Available from: https://www.fda.gov/drugs/fdaapproves-brentuximab-vedotin-previously-untreated-salcl-and-cd30expressing-ptcl. Accessed January 9, 2021.
27. Dupuis J, Morschhauser F, Ghesquières $\mathrm{H}$, et al. Combination of romidepsin with cyclophosphamide, doxorubicin, vincristine, and prednisone in previously untreated patients with peripheral T-cell lymphoma: a non-randomised, phase $1 \mathrm{~b} / 2$ study. Lancet Haematol. 2015;2(4):e160-165. doi:10.1016/S2352-3026(15)00023-X

28. Bachy E, Camus V, Thieblemont C, et al. Final analysis of the ro-CHOP phase III study (conducted by LYSA): romidepsin plus CHOP in patients with peripheral T-cell lymphoma. Blood. 2020;136(Supplement 1):32-33. doi:10.1182/blood-2020-134440

29. Fossard G, Broussais F, Coelho I, et al. Role of up-front autologous stem-cell transplantation in peripheral T-cell lymphoma for patients in response after induction: an analysis of patients from LYSA centers. Ann Oncol. 2018;29(3):715-723. doi:10.1093/annonc/ $\operatorname{mdx} 787$

30. d'Amore F, Relander T, Lauritzsen GF, et al. Up-front autologous stem-cell transplantation in peripheral T-cell lymphoma: NLG-T-01. J Clin Oncol. 2012;30(25):3093-3099. doi:10.1200/ JCO.2011.40.2719

31. Reimer P, Rüdiger T, Geissinger E, et al. Autologous stem-cell transplantation as first-line therapy in peripheral T-cell lymphomas: results of a prospective multicenter study. J Clin Oncol. 2009;27 (1):106-113. doi:10.1200/JCO.2008.17.4870

32. Park SI, Horwitz SM, Foss FM, et al. The role of autologous stem cell transplantation in patients with nodal peripheral T-cell lymphomas in first complete remission: report from COMPLETE, a prospective, multicenter cohort study. Cancer. 2019;125 (9):1507-1517. doi:10.1002/cncr.31861

33. Abeyakoon C, van der Weyden C, Harrop S, et al. Role of haematopoietic stem cell transplantation in peripheral T-cell lymphoma. Cancers (Basel). 2020;12(11):3125. doi:10.3390/cancers12113125

34. Smith SM, Burns LJ, van Besien K, et al. Hematopoietic cell transplantation for systemic mature T-cell non-Hodgkin lymphoma. $J$ Clin Oncol. 2013;31(25):3100-3109. doi:10.1200/JCO.2012.46.0188

35. Schmitz N, Truemper LH, Bouabdallah K, et al. A randomized phase 3 trial of auto vs. allo transplantation as part of first-line therapy in poor-risk peripheral T-NHL. Blood. 2020;(blood.2020008825). doi:10.1182/blood.2020008825

36. Beitinjaneh A, Saliba RM, Medeiros LJ, et al. Comparison of survival in patients with $\mathrm{T}$ cell lymphoma after autologous and allogeneic stem cell transplantation as a frontline strategy or in relapsed disease. Biol Blood Marrow Transplant. 2015;21(5):855-859. doi:10.1016/j. bbmt.2015.01.013

37. Corradini P, Dodero A, Zallio F, et al. Graft-versus-lymphoma effect in relapsed peripheral T-cell non-Hodgkin's lymphomas after reduced-intensity conditioning followed by allogeneic transplantation of hematopoietic cells. J Clin Oncol. 2004;22(11):2172-2176. doi:10.1200/JCO.2004.12.050

38. Zain J, Palmer JM, Delioukina M, et al. Allogeneic hematopoietic cell transplantation for peripheral T-cell NHL results in long-term disease control. Leuk Lymphoma. 2011;52(8):1463-1473. doi:10.3109/10428194.2011.574754

39. O'Connor OA, Pro B, Pinter-Brown L, et al. Pralatrexate in patients with relapsed or refractory peripheral T-cell lymphoma: results from the pivotal PROPEL study. J Clin Oncol. 2011;29(9):1182-1189. doi:10.1200/JCO.2010.29.9024

40. Maruyama D, Nagai H, Maeda Y, et al. Phase I/II study of pralatrexate in Japanese patients with relapsed or refractory peripheral T-cell lymphoma. Cancer Sci. 2017;108(10):2061-2068. doi:10.1111/ cas. 13340

41. Hong X, Song Y, Huang H, et al. Pralatrexate in Chinese patients with relapsed or refractory peripheral T-cell lymphoma: a Single-Arm, Multicenter Study. Target Oncol. 2019;14(2):149-158. doi:10.1007/s11523-019-00630-y

42. Piekarz RL, Frye R, Prince HM, et al. Phase 2 trial of romidepsin in patients with peripheral T-cell lymphoma. Blood. 2011;117 (22):5827-5834. doi:10.1182/blood-2010-10-312603 
43. Coiffier B, Pro B, Prince HM, et al. Results from a pivotal, open-label, phase II study of romidepsin in relapsed or refractory peripheral T-cell lymphoma after prior systemic therapy. $J$ Clin Oncol. 2012;30(6):631-636. doi:10.1200/JCO.2011.37.4223

44. O’Connor OA, Horwitz S, Masszi T, et al. Belinostat in patients with relapsed or refractory peripheral T-cell lymphoma: results of the Pivotal Phase II BELIEF (CLN-19) Study. J Clin Oncol. 2015;33 (23):2492-2499. doi:10.1200/JCO.2014.59.2782

45. Shi Y, Dong M, Hong X, et al. Results from a multicenter, open-label, pivotal phase II study of chidamide in relapsed or refractory peripheral T-cell lymphoma. Ann Oncol. 2015;26(8):1766-1771. doi:10.1093/annonc/mdv237

46. Pro B, Advani R, Brice P, et al. Brentuximab vedotin (SGN-35) in patients with relapsed or refractory systemic anaplastic large-cell lymphoma: results of a phase II study. J Clin Oncol. 2012;30 (18):2190-2196. doi:10.1200/JCO.2011.38.0402

47. Ishida T, Joh T, Uike N, et al. Defucosylated anti-CCR4 monoclonal antibody (KW-0761) for relapsed adult T-cell leukemia-lymphoma: a multicenter phase II study. J Clin Oncol. 2012;30(8):837-842. doi:10.1200/JCO.2011.37.3472

48. Mossé YP, Voss SD, Lim MS, et al. Targeting ALK with crizotinib in pediatric anaplastic large cell lymphoma and inflammatory myofibroblastic tumor: a Children's Oncology Group Study. J Clin Oncol. 2017;35(28):3215-3221. doi:10.1200/JCO.2017.73.4830

49. Horwitz SM, Koch R, Porcu P, et al. Activity of the PI3K- $\delta, \gamma$ inhibitor duvelisib in a phase 1 trial and preclinical models of T-cell lymphoma. Blood. 2018;131(8):888-898. doi:10.1182/blood2017-08-802470

50. Witzig TE, Reeder C, Han JJ, et al. The mTORC1 inhibitor everolimus has antitumor activity in vitro and produces tumor responses in patients with relapsed T-cell lymphoma. Blood. 2015;126 (3):328-335. doi:10.1182/blood-2015-02-629543

51. Lemonnier F, Dupuis J, Sujobert P, et al. Treatment with 5-azacytidine induces a sustained response in patients with angioimmunoblastic T-cell lymphoma. Blood. 2018;132(21):2305-2309. doi:10.1182/blood-2018-04-840538

52. Morschhauser F, Fitoussi O, Haioun C, et al. A phase 2, multicentre, single-arm, open-label study to evaluate the safety and efficacy of single-agent lenalidomide (Revlimid) in subjects with relapsed or refractory peripheral T-cell non-Hodgkin lymphoma: the EXPECT trial. Eur J Cancer. 2013;49(13):2869-2876. doi:10.1016/j. ejca.2013.04.029

53. Ishida T, Fujiwara H, Nosaka K, et al. Multicenter phase II study of lenalidomide in relapsed or recurrent adult T-cell leukemia/lymphoma: ATLL-002. J Clin Oncol. 2016;34(34):4086-4093. doi:10.1200/JCO.2016.67.7732

54. Krishnan C, Warnke RA, Arber DA, Natkunam Y. PD-1 expression in T-cell lymphomas and reactive lymphoid entities: potential overlap in staining patterns between lymphoma and viral lymphadenitis. Am J Surg Pathol. 2010;34(2):178-189. doi:10.1097/ PAS.0b013e3181cc7e79

55. Jo J-C, Kim M, Choi Y, et al. Expression of programmed cell death 1 and programmed cell death ligand 1 in extranodal NK/T-cell lymphoma, nasal type. Ann Hematol. 2017;96(1):25-31. doi:10.1007/ s00277-016-2818-4

56. Kataoka K, Iwanaga M, Yasunaga J-I, et al. Prognostic relevance of integrated genetic profiling in adult T-cell leukemia/lymphoma. Blood. 2018;131(2):215-225. doi:10.1182/blood-2017-01-761874

57. Lesokhin AM, Ansell SM, Armand P, et al. Nivolumab in patients with relapsed or refractory hematologic malignancy: preliminary results of a Phase Ib Study. J Clin Oncol. 2016;34(23):2698-2704. doi:10.1200/JCO.2015.65.9789

58. Kwong Y-L, Chan TSY, Tan D, et al. PD1 blockade with pembrolizumab is highly effective in relapsed or refractory NK/T-cell lymphoma failing 1-asparaginase. Blood. 2017;129(17):2437-2442. doi:10.1182/blood-2016-12-756841
59. Barta SK, Zain J, MacFarlane AW, et al. Phase II study of the PD-1 inhibitor pembrolizumab for the treatment of relapsed or refractory mature T-cell lymphoma. Clin Lymphoma Myeloma Leuk. 2019;19 (6):356-364.e3. doi:10.1016/j.clml.2019.03.022

60. Jain S, Jirau-Serrano X, Zullo KM, et al. Preclinical pharmacologic evaluation of pralatrexate and romidepsin confirms potent synergy of the combination in a murine model of human T-cell lymphoma. Clin Cancer Res. 2015;21(9):2096-2106. doi:10.1158/1078-0432.CCR14-2249

61. Amengual JE, Lichtenstein R, Lue J, et al. A phase 1 study of romidepsin and pralatrexate reveals marked activity in relapsed and refractory T-cell lymphoma. Blood. 2018;131(4):397-407. doi:10.1182/blood-2017-09-806737

62. Marchi E, Zullo KM, Amengual JE, et al. The combination of hypomethylating agents and histone deacetylase inhibitors produce marked synergy in preclinical models of T-cell lymphoma. $\mathrm{Br}$ J Haematol. 2015;171(2):215-226. doi:10.1111/bjh.13566

63. O'Connor OA, Falchi L, Lue JK, et al. Oral 5-azacytidine and romidepsin exhibit marked activity in patients with PTCL: a multicenter phase 1 study. Blood. 2019;134(17):1395-1405. doi:10.1182/blood.2019001285

64. Horwitz SM, Moskowitz AJ, Jacobsen ED, et al. The combination of duvelisib, a PI $3 \mathrm{~K}-\delta, \gamma$ inhibitor, and romidepsin is highly active in relapsed/refractory peripheral T-cell lymphoma with low rates of transaminitis: results of parallel multicenter, phase 1 combination studies with expansion cohorts. Blood. 2018;132(Supplement1):683. doi:10.1182/blood-2018-99-115241

65. Tan D, Phipps C, Hwang WYK, et al. Panobinostat in combination with bortezomib in patients with relapsed or refractory peripheral T-cell lymphoma: an open-label, multicentre phase 2 trial. Lancet Haematol. 2015;2(8):e326-333. doi:10.1016/S2352-3026(15)000976

66. Honma D, Kanno O, Watanabe J, et al. Novel orally bioavailable EZH1/2 dual inhibitors with greater antitumor efficacy than an EZH2 selective inhibitor. Cancer Sci. 2017;108(10):2069-2078. doi: $10.1111 /$ cas. 13326

67. Maruyama D, Tobinai K, Makita S, et al. First-in-human study of the EZH1/2 dual inhibitor DS-3201b in patients with relapsed or refractory non-hodgkin lymphomas - preliminary results. Blood. 2017;130(Supplement1):4070. doi:10.1182/blood.V130. Suppl_1.4070.4070

68. Kallam A, Witzig TE, Roschewski MJ, et al. Phase II multi-center study of ruxolitinib phosphate for the treatment of relapsed or refractory diffuse large B-cell lymphoma (DLBCL) and peripheral T-cell lymphoma (PTCL). JCO. 2019;37(15_suppl):e19063-e19063. doi:10.1200/JCO.2019.37.15_suppl.e19063

69. Mehta-Shah N. Emerging strategies in peripheral T-cell lymphoma. Hematology Am Soc Hematol Educ Program. 2019;2019(1):41-46. doi:10.1182/hematology.2019000012

70. Spinner S, Crispatzu G, Yi J-H, et al. Re-activation of mitochondrial apoptosis inhibits T-cell lymphoma survival and treatment resistance. Leukemia. 2016;30(7):1520-1530. doi:10.1038/leu.2016.49

71. Wang L, Wang H, Li P, et al. CD38 expression predicts poor prognosis and might be a potential therapy target in extranodal NK/T cell lymphoma, nasal type. Ann Hematol. 2015;94(8):1381-1388. doi:10.1007/s00277-015-2359-2

72. Huang H, Kim W-S, Yao M, et al. Daratumumab monotherapy for patients with relapsed or refractory (R/R) Natural Killer/T-Cell Lymphoma (NKTCL), nasal type: updated results from an Open-Label, Single-Arm, Multicenter Phase 2 Study. Blood. 2019;134(Supplement_1):1568. doi:10.1182/blood-2019-123446

73. Hartmann F, Renner C, Jung W, et al. Anti-CD16/CD30 bispecific antibody treatment for Hodgkin's disease: role of infusion schedule and costimulation with cytokines. Clin Cancer Res. 2001;7 (7):1873-1881. 
74. Bartlett NL, Herrera AF, Domingo-Domenech E, et al. A phase 1b study of AFM13 in combination with pembrolizumab in patients with relapsed or refractory Hodgkin lymphoma. Blood. 2020;136 (21):2401-2409. doi:10.1182/blood.2019004701

75. Amatore F, Ortonne N, Lopez M, et al. ICOS is widely expressed in cutaneous T-cell lymphoma, and its targeting promotes potent killing of malignant cells. Blood Adv. 2020;4(20):5203-5214. doi:10.1182/ bloodadvances.2020002395

76. Wang C-M, Wu Z-Q, Wang Y, et al. Autologous T cells expressing CD30 chimeric antigen receptors for relapsed or refractory hodgkin lymphoma: an open-label phase I trial. Clin Cancer Res. 2017;23 (5):1156-1166. doi:10.1158/1078-0432.CCR-16-1365

77. Ramos CA, Ballard B, Zhang $\mathrm{H}$, et al. Clinical and immunological responses after $\mathrm{CD} 30$-specific chimeric antigen receptor-redirected lymphocytes. J Clin Invest. 2017;127(9):3462-3471. doi:10.1172/ JCI94306
78. Maciocia PM, Pule MA. Anti-CD1a CAR T cells to selectively target T-ALL. Blood. 2019;133(21):2246-2247. doi:10.1182/blood-201903-900910

79. Mehta-Shah N, Moskowitz AJ, Lunning MA, et al. A phase Ib/IIa trial of the combination of romidepsin, lenalidomide and carfilzomib in patients with relapsed/refractory lymphoma shows complete responses in relapsed and refractory B- and T-cell lymphomas. Blood. 2017;130(Supplement 1):821. doi:10.1182/blood.V130. Suppl_1.821.821

\section{Publish your work in this journal}

The Journal of Experimental Pharmacology is an international, peerreviewed, open access journal publishing original research, reports, reviews and commentaries on all areas of laboratory and experimental pharmacology. The manuscript management system is completely online and includes a very quick and fair peer-review system. Visit http://www.dovepress.com/testimonials.php to read real quotes from published authors.

Submit your manuscript here: https://www.dovepress.com/journal-of-experimental-pharmacology-journal 